\title{
More Balanced Election Coverage with Media Researchers on Location
}

\author{
Tomas Andersson Odén
}

On 15 August 2004, the Bolivarian Republic of Venezuela held a referendum to decide if the current president, Hugo Chávez, should remain in office until the end of his six-year term or be recalled. Because of strong social tension, including friction between Chavez and some of the private media companies, the Atlanta-based democracy organisation The Carter Center sent a mission to Venezuela to observe the referendum. The Carter Project included a Scandinavian media monitoring project to assess whether election coverage in the major TV channels' newscasts was balanced or biased. ${ }^{1}$

The result of the media monitoring was reported each week to the media companies and to the Venezuelan National Electoral Council (CNE). The first report, released on 22nd of July 2004 demonstrated that only one of the newscasts had a relatively balanced election reporting while the others had a considerable bias. ${ }^{2}$ One of those was state-owned channel Venezolana de Televisión (VTV), where news reporting strongly supported the president. Shortly after the report was presented, the chief editor of VTV, Mr. Vladimir Villegas, announced publicly that he accepted the methodology and the results of the monitoring, and promised that reporting on his channel would become more balanced.

The monitoring that followed showed that VTV's election reporting in fact did become more balanced in the weeks leading up to the referendum. The same happened with newscasts on several commercial channels.

On the 4th of December 2006, Venezuelans should once again decide on the future of president Chávez, this time in normal presidential elections and with less presence from The Carter Center, wich devoted no resources to monitoring of the media. ${ }^{3}$ Nonetheless, JMG at the University of Gothenburg, in collaboration with Norwegian journalist Stein Ove Gronsund, Miami carried out a monitoring project. A group of Venezuelan students who had been trained and had participated in the 2004 monitoring were recruited as coders. ${ }^{4}$

The purpose of the 2006 monitoring project was to analyse the balance in the coverage of the presidential election campaign, and to evaluate the methodology of the 2004 project.

The main question was whether there were reasons to assume that the increased balance in media reporting in 2004 was due to the media monitoring project and the weekly presentation of its results.

\section{Tension after Coup}

Tension between the Venezuelan president and some of the privately-owned TV channels was partly due to the media's alleged role in a coup d'état that briefly deposed of Hugo Chávez in April of 2002. He had then been president for four years, but had harboured power ambitions for much longer. Chávez made a first push to gain power in 1992. He was a lieutenant colonel in the paratrooper regiment at the time, and tried to seize power from then president Carlos Andrés Pérez by launching a military coup. The coup failed, and Chávez was sent to prison but pardoned a few years later (Cederberg \& Källstrand, 2003).

In 1998, Chavez became president through an ordinary election process. Disenchantment with the old parties increased his popularity, also among the media. Some of this media support had disappeared by 1999 , however, when he was re-elected after a new Constitution was approved by referendum earlier the same year. The media were afraid that this new constitution would limit the freedom of the press (Tanner Hawkins, 2003). However, Chávez won the re-election with a clear majority.

In April 2002, some of the opposition tried to overthrow Chávez. One of the opposition leaders, 
businessman Pedro Carmona, functioned as president for a few days before Chavez returned to power. The media's role in the attempted coup has been the subject of intense debate. It has been asserted that some of the TV channels were actively involved in the coup (Klein, 2003). Since the coup, relations between the President and the private TV channels have been strained.

\section{Demands for Objectivity and Balance}

As a consequence, the 2004 media monitoring project took place in a strongly polarized society with an unstable democratic situation. The project was part of a larger election observation led by The Carter Center.

Growing insight into the significance of the media during election campaigns has led to that election observation in recent years has been increasingly supplemented with projects to monitor the media's campaign reporting. Two examples are the media monitoring of elections in Mexico (Valverde \& Rosales, 1994) and Palestine (Palestinian Initiative for the Promotion of Global Dialogue and Democracy, 2005). The Swedish international development agency, Sida, also planned to finance a Danish-led media monitoring project in the Middle East but plans were shelved when tension flared between Denmark and the Muslim world.

The growing interest in the monitoring of media during election campaigns warrants a discussion on the format and methodology of these projects. One question is whether they are at all effective; another is how they should be designed to achieve the desired effect. The very idea of trying to influence the media's dissemination of news and opinion building can also be discussed.

In Venezuela in 2004, it was not the international corps of observers that made demands on the media, but the country's own electoral council. Before the referendum, the National Electoral Council (CNE) signed an agreement with radio and TV companies where the media organisations committed themselves to an objective and balanced election reporting. (Resolución no 040701-1069, CNE, Caracas).

This kind of demands is not unreasonable in a democratic society. Kent Asp summarizes the role of media in a representative democracy as follows: "In a democracy media should work for the realization of the will of the people by facilitating the free exchange of ideas." The media carry out this task by scrutinizing the government, and conveying information that enables citizens to freely and independ- ently form opinions on social issues. And for citizens to form opinions, the media has to inform them about political issues, and disseminate fair views and opinions about those issues (Asp, 2007).

The Venezuelan electoral council's demands for objectivity and balance are not an unreasonable operationalization of these demands for information and the fair dissemination of views and opinion. The formulation is also similar to regulations relating to public service broadcasting in Western Europe. At the same time, government demands on the content of news media can be problematic. The media's right to freely and independently decide over their news services is one of the most basic qualifications of a functioning democracy.

Neither is reducing the polarization in media reporting necessarily positive. In societies with strong traditions of consensus, polarization may be a useful tool for presenting alternatives. However, in societies with strong mistrust between different social groups, contributing to less polarization may be desirable, so that the media at least presents the different alternatives that exist, and treats the most important alternatives with reasonable equality. This contributes to voters forming their own opinions, and improves the chances of realizing the opinions of the people through elections.

Finally, monitoring and reporting media coverage does not restrict press freedom. And publishing the results of media monitoring during an ongoing election campaign can increase opportunities for citizens to acquire information from balanced news media.

\section{The Media Project in Venezuela}

The purpose of this report is to analyse the effects of the media monitoring during the last weeks of campaign before the Venezuelan recall referendum in 2004.

The coded material consists of news items from five major Venezuelan TV channels during the two election campaigns in 2004 and 2006. One of the channels - VTV - is owned by the Venezuelan Government, while the other four - Radio Caracas Televisión (RCTV), Venevisión, Televen and Globovisión - are privately owned.

The monitored period in 2004 was from the 16th of July to the 15th of August. Every day on weekdays Monday to Friday, and on the final Saturday and Sunday, the project analysed news reporting on the election campaign in two newscasts on each of the TV channels. A total of 220 newscasts were analysed, which means 44 newscasts per channel. In 
2006, the monitored period was from the 6th of November to the 1 st of December. On weekdays one newscast per day was analysed, totalling 100 newscasts or 20 newscasts per channel.

In 2004, the monitoring was carried out on location in Caracas, and the results were presented periodically during the ongoing election campaign. In 2006, the monitoring was carried out as discreetly as possible: no results were disclosed during the election campaign and much of the work was carried out from a distance. Only coding of the newscasts' content took place on location in Caracas. The project was managed from Gothenburg and Miami.

Both in 2004 and 2006 the media monitoring projects were performed using quantitative content analysis of the TV stations' news coverage of the referendum, respectively the presidential election. This methodology has been applied and developed over a period of several years by the Department for Journalism and Mass Communication, Göteborg University (see Asp et. al, 1982; Asp, 1991; Asp, Johansson \& Nilsson 2000, Andersson Odén \& Wadbring, 2003).

In both 2004 and 2006, news dominated the analysed material in the form of wire copy, interviews and other news stories. But there were also some elements of opinion-forming content such as chronicles and editorials. In both years some transmissions were interrupted by government messages, the so called cadenas, which almost always contained some form of speech by president Chávez. During both of the monitored periods, primarily private channel Globovisión and state-owned VTV were affected by these "messages".

The total number of analysed editorial content, including cadenas, during the first monitored period was 2,142 , and during the second monitored period 1,125 (Table 1). In addition, the analysis during the second monitored period included 406 reports with political advertisements that were broadcast in direct connection with newscasts. This type of advertisements was not included in the 2004 analysis.

However, news dominated in both monitoring periods and most of the analysis is performed on this material. The actual monitored material from 2004 is therefore 1,973 news items, while the material from 2006 consists of 1,042 news items.

The local coding work in Venezuela during both periods was carried out by coders recruited from senior classes and newly graduated students in journalism or communication science from leading universities in Caracas. The 2004 monitoring period was preceded by a training course, where the students were trained in the methodology and the analysis tools. Coding in the 2006 period was carried out by six of the most experienced assistants from the 2004 project.

\section{Less Balance in 2006}

The question presented to the electorate in the recall referendum of 2004 was whether President Chavez should be removed from his post, or continue to govern for the rest of his mandate period. In simple terms, it was a vote for or against Chávez.

The elections in 2006 were to choose a president. The issue was complicated at first because more than 20 candidates stood for election. But opinion polls a few months before the referendum showed clearly that only two candidates held any chance of winning: the current president, Hugo Chávez and the governor of Venezuela's most populous state Zulia, $\mathrm{Mr}$ Manuel Rosales, who was supported by the largest opposition parties. A third candidate, Mr. Benjamin Rausseo, registered a small percentage of support in some polls while other candidates played no role whatsoever. When Rausseo withdrew his candidature a few weeks before the election, only two serious

Table 1. Coded TV News Items, 2004 and 2006. Type of Items (number)

\begin{tabular}{|c|c|c|c|c|c|c|c|c|c|c|c|c|}
\hline & \multicolumn{2}{|c|}{ RCTV } & \multicolumn{2}{|c|}{ Venevision } & \multicolumn{2}{|c|}{ Televen } & \multicolumn{2}{|c|}{ Globovision } & \multicolumn{2}{|c|}{ VTV } & \multicolumn{2}{|c|}{ Totalt } \\
\hline & 2004 & 2006 & 2004 & 2006 & 2004 & 2006 & 2004 & 2006 & 2004 & 2006 & 2004 & 2006 \\
\hline Editorials & 12 & 6 & 1 & 0 & 3 & 1 & 2 & 1 & 2 & 7 & 20 & 15 \\
\hline Chronicles & 18 & 5 & 1 & 0 & 8 & 6 & 4 & 1 & 1 & 0 & 32 & 12 \\
\hline News & 460 & 289 & 399 & 240 & 279 & 132 & 475 & 248 & 360 & 133 & 1,973 & 1,042 \\
\hline Cadenas & 0 & 1 & 0 & 6 & 1 & 2 & 16 & 13 & 16 & 13 & 33 & 35 \\
\hline $\begin{array}{l}\text { Other } \\
\text { news items }\end{array}$ & 12 & 9 & 3 & 1 & 8 & 5 & 29 & 0 & 32 & 6 & 84 & 21 \\
\hline Total & 502 & 310 & 404 & 247 & 299 & 146 & 526 & 263 & 411 & 159 & 2,142 & 1,125 \\
\hline
\end{tabular}

Note: In addition to these items, 406 advertising items have been coded in the 2006 monitoring. No equivalent coding of advertising was carried out in 2004. The advertising is in 2006 distributed between RCTV (27 reports), Venevisión (49), Televen (55), Globovisión (101) and VTV (174). 
candidates remained: Chávez and Rosales. The election was reduced to choosing one of these two men as president. And the main question in the media monitoring became how TV newscasts treated each of these candidates. ${ }^{5}$

The monitoring aimed to assess the balance in TV channels' election reporting. Individual TV channels can achieve balance in two ways: by presenting each individual report neutrally, for example by allowing both parties to express their views, or by broadcasting an equal number of reports in either candidate's favour.

During both election campaigns, roughly half of the news items were neutral while the other half was biased, either because reports were clearly tilted towards one side or the other, or because one of the parties was allowed to dominate. Dominance in the latter case was usually total because the views of only one party were presented (Table 2).

In both of the monitored periods, the percentage of neutral reports was highest for the two private TV companies Televen and Venevisión, while the other private companies and the state-owned TV company, VTV, had a lower percentage of neutral reports. In the second monitored period, 2006, the percentage of neutral reports was also relatively large for state-owned VTV.

In the weekly reports of the monitoring results during the referendum campaign in 2004, great emphasis was placed on the percentage of neutral reports. On all TV channels except one, the percent- age of neutral news reports also increased after the first report was presented on the 22nd of July, and this increase was pronounced for three of the channels. The channel that did not increase its percentage of neutral reports was RCTV, where the percentage remained more or less constant (Table 3 ).

In the 2006 monitoring, the pattern was almost the opposite. One channel, RCTV, increased its percentage of neutral reports during the second half of the election campaign, while the percentage for one channel remained constant. But for the other three channels, the percentage of neutral reports dropped during the latter part of the election campaign, and this reduction was significant for two of them.

The results imply that the weekly presentation of monitoring results during the 2004 referendum campaign encouraged more balanced election reporting to the extent that it increased the percentage of neutral news reports.

The question is then whether this also applies for the half of the news reporting that was not balanced in the sense that each individual report was neutral. As it only occurred in exceptional cases that news channels were clearly biased in their news reports, these reports will in future be handled together with the reports that were biased in the sense that one side dominated.

Also in this part of the news reporting, more balance was noticed for three of the TV companies in 2004 after the first report was presented, specifically privately-owned Venevisión and Televen and

Table 2. Journalistic Form of News Reports in 2004 and 2006 (\%)

\begin{tabular}{lrrrrrrrrrr} 
& \multicolumn{2}{c}{ RCTV } & \multicolumn{2}{c}{ Venevision } & \multicolumn{2}{c}{ Televen } & \multicolumn{2}{c}{ Globovision } & \multicolumn{2}{c}{ VTV } \\
& 2004 & 2006 & 2004 & 2006 & 2004 & 2006 & 2004 & 2006 & 2004 & 2006 \\
\hline Report clearly biased & 2 & 1 & 2 & 0 & 4 & 4 & 7 & 7 & 16 & 11 \\
One side dominates & 52 & 55 & 46 & 45 & 36 & 35 & 48 & 61 & 47 & 35 \\
Neutral information & 45 & 44 & 52 & 55 & 60 & 61 & 45 & 32 & 37 & 53 \\
N= number of reports & 460 & 289 & 399 & 240 & 279 & 132 & 475 & 248 & 360 & 133 \\
Number of reports per newscast & 10.5 & 14.5 & 9.1 & 12.0 & 6.3 & 6.6 & 10.8 & 12.4 & 8.2 & 6.7 \\
\hline
\end{tabular}

Table 3. Percentage of Neutral Reports in TV Newscasts (\%)

\begin{tabular}{lcccccc} 
& & Referendum, 2004 & \multicolumn{4}{c}{ Presidential election, 2006 } \\
& 16-21 July & $22 / 7-15 / 8$ & Difference & Week 45-46 & Week 47-48 & Difference \\
\hline RCTV & 46 & 45 & -1 & 37 & 50 & +13 \\
Venevisión & 36 & 55 & +19 & 64 & 47 & -17 \\
Televen & 50 & 60 & +10 & 71 & 55 & -16 \\
Globovisión & 43 & 46 & +3 & 31 & 32 & +1 \\
VTV & 21 & 38 & +17 & 58 & 51 & -7 \\
\hline
\end{tabular}

Note: When measuring the difference, the plus sign indicates a higher percentage of neutral reports, while the minus sign indicates a lower percentage of neutral reports. 
state-owned VTV. There was no marked change for RCTV and a slightly decreased balance for the remaining Globovisión (Table 4).

In the 2006 monitoring period, the balance deteriorated for all TV companies during the second half of the election campaign. For two of the TV channels, Venevisión and Televen, the deterioration was marginal. In the case of Televen, a previous weak imbalance was in fact adjusted. For the three remaining channels, however, the deterioration was significant. Two of the channels, privately-owned RCTV and Globovisión, became increasingly positive towards the opposition, while state-owned VTV became increasingly positive towards the current president.

The results thus show that periodical presentation of the results in 2004 contributed not only to increase the percentage of neutral news reports, but also to improve balance in the reports that were biased towards one side or the other.

\section{Government Propaganda}

Finally, it is important to point out that the balance in news reports on the different TV channels does not tell us everything about their overall TV programming. As newscasts also include other reports, the balance does not even apply for the total news coverage.

As shown in Table 1, the Venezuelan TV companies' newscasts included a limited number of editorials and opinion pieces from the newsroom. There were also interruptions for government messages or cadenas, which were generally speeches and appearances by president Chávez. Even if the number of the number of cadenas was relatively few, it does not mean that they were without importance.

But most of all, the 2006 content analysis shows that political advertising in connection with newscasts was extensive (corresponding monitoring was not carried out in 2004). A total of 406 political ads were registered, either as interruptions during newscasts or immediately before and after the broadcasts. In the term "political advertising", we have also included political and social messages produced by the Venezuelan government and disseminated according to the so called Ley Resorte. ${ }^{6}$

The largest individual advertiser was the Venezuelan Government, representing 140 ads during the monitored period. Some ads were broadcast by the private TV companies, but a much higher percentage, 80 percent, were broadcast by state-owned VTV. Government advertising was almost exclusively biased towards president Chávez, which strongly impacted the total programming in connection with state-owned VTV's newscasts. The second largest advertiser was opponent Rosales' election organization, with 75 registered ads. These ads were broadcast on all channels, but mainly on Globovisión and RCTV, and were of course biased towards Rosales. President Chavez' election organization was responsible for 59 ads, which were broadcast on all channels except RCTV, but especially on Televen. These ads also impacted the total programming of the different channels. Other elements were interruptions for government messages (cadenas) and the newsrooms' own opinion pieces, although these were fewer.

Non-news items had the greatest impact on the total programming on state-owned VTV, where the strong pro-government bias became even more pronounced because of government ads. Programming on three of the private channels also became more pro-government, while RCTV's anti-government bias increased because of advertising for opposition candidates and lack of advertising for the President (Table 5).

Table 4. Balance in TV Reports (\%)

\begin{tabular}{lccccccc} 
& \multicolumn{3}{c}{ Referendum, 2004 } & & \multicolumn{3}{c}{ Presidential election, 2006 } \\
\cline { 2 - 4 } \cline { 6 - 7 } & $16-21$ July & $22 / 7-15 / 8$ & Difference & & Week 45-46 & Week 47-48 & Difference \\
\hline RCTV & -39 & -38 & +1 & & -25 & -38 & -13 \\
Venevisión & -29 & -8 & +21 & & -5 & -8 & -3 \\
Televen & +17 & +7 & +10 & -8 & -13 & -29 & -3 \\
Globovisión & -17 & -25 & +14 & +33 & +54 & -21 \\
VTV & +63 & +49 &
\end{tabular}

Note: When measuring the difference, the plus sign indicates better balance between the parties, while the minus sign indicates less balance. The balance in 2004 is calculated as the difference "for Chavez" minus "against Chavez". The balance in 2006 is calculated as the difference in "positive for Chavez" minus "positive for Rosales". (One alternative, calculating the balance as the difference between the reports that are negative for each candidate, gives a similar result). 
Table 5. Balance in TV Channels' News Material, and in the Total Material, in Connection with Newscasts in 2006

\begin{tabular}{|c|c|c|c|c|c|c|c|c|c|c|c|c|}
\hline & \multicolumn{2}{|c|}{ RCTV } & \multicolumn{2}{|c|}{ Venevision } & \multicolumn{2}{|c|}{ Televen } & \multicolumn{2}{|c|}{ Globovision } & \multicolumn{2}{|c|}{ VTV } & \multicolumn{2}{|c|}{ Total } \\
\hline & News & All & News & All & News & All & News & All & News & All & News & All \\
\hline Balance Cha & & & & & & & & & & & & \\
\hline - Rosales & -32 & -35 & -6 & -1 & -2 & +11 & -22 & -13 & +47 & +68 & -10 & +5 \\
\hline $\begin{array}{l}\text { Neutral } \\
\text { information }\end{array}$ & 44 & 43 & 55 & 47 & 61 & 48 & 32 & 26 & 53 & 34 & 47 & 38 \\
\hline $\begin{array}{l}\mathrm{N}=\text { number } \\
\text { of reports }\end{array}$ & 289 & 337 & 240 & 296 & 132 & 201 & 248 & 364 & 133 & 333 & 1,042 & 1,531 \\
\hline
\end{tabular}

Note: The total material (All) includes news, opinion pieces, "cadenas" and political advertisements in connection with newscasts.

\section{Real Time Reports had an Impact}

The main purpose of the media monitoring project in 2006 was to evaluate the methodology used in the 2004 project. The most important conclusion is that being on location during the pre-election period and present reports of monitoring results during the campaign can affect the media content. The presence of media researchers in Venezuela in 2004 seems to have had a significant effect. The 2006 media monitoring project, which was not directly reported to Venezuelan media and may in fact never have been noticed, showed increased polarization in the media's news offering. The corresponding monitoring project in 2004 with the monitoring group present and visible, combined with the periodical reports of the results during the election campaign, showed less polarization. The only reasonable conclusion is that the monitoring in 2004 contributed to a more balanced TV news coverage.

The monitoring of advertising in 2006 also shows that monitoring should not be limited to news material. In countries where the government exercises strong control over TV programming, demands for balance can be circumvented by supple- menting relatively neutral newscasts on state-owned television with massive state-funded advertising campaigns. Correspondingly a wealthy candidate can distort programming by buying advertising time.

Another experience from the follow-up project in 2006 is that modern technology enables media monitoring from a distance. Because of access to local assistants trained in the methodology, the project could be managed thousands of kilometres away from the centre of events. If television channels broadcast digitally or via satellite, the entire monitoring process can be carried out from a distance, provided that coders with good language skills are available. In the 2006 media monitoring project, some of the control coding of a digital TV channel was carried out in Miami.

This model should not be pushed too far, however; local knowledge, knowledge of social codes, etc. can be important for interpreting the media's news content. There are also other benefits to be gained from local presence, in particular direct contact with coders and media companies. Last but not least, local presence increases opportunities for presenting the monitoring results to interested and affected parts of the media public.

\section{Notes}

1. The Scandinavian project was financed by the Norwegian Ministry for Foreign Affairs and led by Stein Ove Grønsund from Norway and Tomas Andersson Odén from Sweden. The results of the monitoring have been presented in: Andersson Odén (2005). Some of the results are also available from The Carter Center (2005).

2. The most neutral company, Televen, broadcast only 12 news reports on the referendum during the first few days. The other companies broadcast between 24 and 46 reports during the same period.

3. A minor monitoring project was included in an EU Election Observation Mission, reported in: Final Report. Presidential Elections Venezuela 2006.

4. The project in 2006 was financed by JMG, Göteborg University. 
5. One of the 20 presidential candidates appears in 645 of the news reports that were coded in 2006. Of these, President Chavez appears in 300 reports, his main opponent Rosales in 318, Rausseo in 13 and some of the other candidates in a total of 14 reports.

6. According to the law Ley de Responsabilidad Social en Radio y Televisión of $31^{\text {st }}$ of January 2005, the government has the right to disseminate, free of charge, a total of 70 weekly minutes of information in electronic media. The law is normally referred to as Ley Resorte.

\section{References}

Andersson Odén, Tomas \& Wadbring, Ingela (2003) Teknisk rapport för publicistiska bokslut. Göteborgs universitet: JMG (Arbetsrapport nr 10).

Andersson Odén, Tomas (2005) President Chavez i press, radio och TV. Mediebevakningen av folkomröstningskampanjen $i$ Venezuela, augusti 2004. Göteborgs universitet: JMG (Arbetsrapport nr 29).

Asp, Kent m.fl (1982) Väljare, partier, massmedia. Empiriska studier $i$ svensk demokrati. Liber förlag.

Asp, Kent (1991) Partiskheten i Sveriges radios och TV4:s nyhetsprogram under 1991 års valrörelse: en undersökning av valbevakningen $i$ Rapport, Aktuellt, Ekot, Nyheterna och Dagens nyheter. Göteborgs universitet: JMG (Arbetsrapport nr 16).

Asp, Kent, Johansson, Bengt \& Nilsson, Åsa (2000) Medievalsundersökningen 1998. Teknisk rapport. Göteborgs universitet: JMG (Arbetsrapport nr 98).

Asp, Kent (2007) Fairness, Informativeness and Scrutiny. The Roles of News Media in Democracy. Forth- coming in: Helland, Knut \& Carlsson, Ulla (eds). Media Structures and Practices. As Time Goes By.... Studies and Reflections from a Scandinavian Horizon. Nordicom Review, Jubilee Issue, 2007

Cederberg, Ingemar \& Källstrand, Martin (2003) Landöversikt Venezuela. Report from Swedish embassy in Bogota 2003-03-10.

European Union Election Observation Mission: Final report. Presidential Elections, Venezuela 2006. $<$ www.eueomvenezuela.org >

Klein, Naomi (2003) Venezuela's Media Coup. The Nation, March 3.

Monitoring the Media Coverage of the 2005 Presidential Elections in Palestine. The Palestinian Initiative for the Promotion of Global Dialogue and Democracy, 2005.

Monitoring the Coverage of the October 2004 Legislative and Presidential Elections in Tunisia. The Tunisian League for the Defence of Human Rights, 2004.

Tanner Hawkins, Eliza (2003) Conflict and the Mass Media in Chávez's Venezuela. Provo, Utah (unpublished).

The Carter Center (2005) The Carter Center and the Peacebuilding Process in Venezuela, june 2002 february 2005.

Valverde, Miguel Acosta \& Parra Rosales, Luz Paula (1994) The Media and the 1994 Federal Elections i Mexico: A content analysis of Television News Coverage of the Political Parties and Presidental Candidates (english version of Guia para el análisis de contenido electoral de medios de communicación. Mexico City: Academia Mexicana de Derechos Humanos, 1994). 